\title{
Љубомир Поповић
}

\section{ИНТЕГРАЛНИ МОДЕЛ МЕЪУОДНОСА СИНТАКСИЧКОГ СИСТЕМА, РЕЧНИКА И ТЕКСТОВА}

Циљ овог рада је (1) да понуди један могући теоријски оквир за повезивање синтаксичког система, речника (лексикона) и реченица одн. текстова, и то како са гледишта језичке продукције, тако и са гледишта језичке интерпретације; и (2) да тиме подстакне интегрисање синтаксичког и лексичког приказа српског књижевног језика.

\section{1. Интерфејси (сумеђе) синтаксичког система, речника и текстова}

\section{1. Повезаност синтаксичког система и речника (лексикона)}

Као оквир за повезивање синтаксичког система и речника (лексикона) може да послужи концепција природног језика као продукционо-интерпретационог система који чине (1) разни језички (под)системи везани за одговарајуће нивое језика и (2) речник (лексикон). Уз то су и системи међусобно, и системи и речник повезани одговарајућим међуодносима и везама, који чине сумеђ ${ }^{1}$, односно интерфејсе (енгл. interface), одговарајућих компоненти језика.

За овај рад је битан граматички систем, који чине четири ужа система. систем врста речи и њихових граматичких категорија, систем промене речи, систем творбе речи и синтаксички систем². Први систем типизира (систематише, класификује) лексеме у одређене врсте и подврсте речи, с

1 Термин сумеђа је преузет из „Оксфордског речника рачунарства” (Београд: Нолит, 1990).

2 Термин граматички је овде употребљен у значењу ближем терминологији традиционалне и структуралистичке него генеративне лингвистике. Прва три система се у традиционалној лингвистици групишу у морфолошки систем (тачније, морфологију), с тим што се промена речи сматра морфологијом у ужем 
тим што се некима обавезно додају одговарајуће вредности класификационих (= инхерентних) граматичких категорија, нпр. именицама род, а глаголима вид 3 ; а на основу парадигматских система који се реализују разним типовима промене, променљивим речима се обавезно 4 додају и вредности одређених морфолошких граматичких категорија. Други систем (морфолошки систем у ужем смислу) даје обрасце промена речи, као формални аспекат морфолошких категорија. Систем творбе речи даје - више или мање продуктивне и више или мање „стегнуте” (енгл. constrained) - обрасце на основу којих су мотивисане творбене везе између постојећих, граматички систематисаних, лексема и на основу којих се могу систематски правити нове творенице. ${ }^{5}$ А синтаксички систем, регулишући могуће конструкције и распореде унутар (комуникативне) реченице, регулише и употребу граматички систематисаних лексема у реченици (како пунозначних тако и помоћних), укључујући и употребу граматичких облика променљивих лексема.

Из овога произлазе две чињенице. Пре свега, речник није само фонд лексема, односно речи као јединица са стандардним (устаљеним) индивидуалним материјалним обликом (са одређеним варијацијама, ако је лексема променљива) који стоји у корелацији са индивидуалним значењем (моносемичне лексеме) или породицом сродних значења (полисемичне лексеме); него се ради и о: (1) граматички систематисаним лексемама (врсте речи и класификационе категорије), (2) које, ако су променљиве, имају одређене морфолошке категорије односно одговаpajуће граматичке облике и (3) које, ако су творбено мотивисане, стоје у граматичким творбеним везама са другим лексемама. Дакле, не ради

смислу. Међутим, систем врста речи и њихових категорија, подједнако важан и за синтаксу, пре би се могао означити као морфосинтаксички систем.

${ }^{3}$ Ове две категорије су наведене као пример, а не као исцрпан списак класификационих категорија.

${ }^{4}$ Оно важи за категорије реализоване деклинацијом и конјугацијом; степен поређења је посебан случај (не треба заборавити да се компарација налази на граници промене и творбе речи).

${ }^{5}$ Морфолошки системи (системи промене и творбе, одн. парадигматски и творбени систем) имају као заједничку компоненту морфемски систем. Тај систем класификује - аналогно врстама речи - лексичке морфеме (корене); одређује граматичке (парадигматске и творбене) вредности граматичких морфема, тј. афикса; и - у свом морфотактичком делу - даје обрасце и „стеге” за комбиновање и распоређивање морфема. А као интерфејс (сумеђа) морфолошких и фонолошког система јавља се морфофонолошки систем, одн. систем фонемских и акценатских алтернација, који садржи обрасце и „стеге” за формирање одговарајућих формалних варијанти морфема (аломорфа). 
се само о лексици него и о лексикону, и то као компоненти језика која је интегрисана са одговарајућим језичким (под)системима и која обухвата како речи, са њиховим лексемским и граматичким аспектима, тако и граматичке облике речи, са њиховим категоријалним вредностима.

Наравно, да би слика о лексикону била потпуна, овоме треба додати и везу лексема са другим језичким системима. За овај рад је битна његова веза са синтаксичким системом, при чему се узајамна интегрисаност синтаксичког система и лексикона може означити као синтаксичко-лексички интерфејс (или сумеђа).

\section{2. Неколико напомена}

1. Речник обухвата не само лексеме него и разне лексикализоване изразе (терминолошке изразе, сложене називе, фразеологизме и сл.). Ту се чак може радити и о лексикализацији, тј. укључивању у речник, и (фрагмента) текста, као што је случај са следећом пословицом у виду дијалога:

(1) „Ко ти ископа око?”

„Брат.”

„Зато је тако дубоко."

Ништа лепше не карактерише нашу љуту борбу у првом устанку од ове пословице народне. (Ј. Веселиновић, Хајдук Станко, Београд, 1952, стр. 381).

Из овога проистиче да би за напред констатовану интеграцију синтаксичког система и лексикона прецизнији назив био синтаксичко-лексемски интерфејс. (О вези синтаксичког система и лексикализованих израза овде више неће бити речи.)

2. Речник представља скуп нејасних граница, који наликује ономе што се у математици подразумева под појмом расплинути (енгл. fuzzy) скуn. „Расплинутост” речника условљена је разним факторима. Пре свега, то је отворен скуn, који се не само проширује позајмицама и семантичким иновацијама ${ }^{6}$ него, захваљујући продуктивним обрасцима творбеног система (укључујући и творбу полусложеница и неких типова скраћеница), има могућност за системско проширивање фонда главних

${ }^{6}$ Овоме треба додати могућности разних типова ad hoc померене употребе основног значења речи: један пример:

Умјесто тога грађени су капацитети целулозе и других „целулоза”... (Политика, 14. IV 1991, 10). 
врста речи. ${ }^{7}$ Уз то и ономатопејски узвици представљају отворену класу, али не на основу творбеног система, него на основу имитативно-експресивне креативности припадника дате језичке заједнице. При том су све врсте иновирања праћене различитим степенима лексикализованости нових лексема, и то као динамичном појавом, што значи да нове јединице нису у подједнакој мери чланови речника. А динамичност лексикона огледа се, наравно, не само у (потенцијалним) иновацијама него и у губљењу лексема из (активног) речника.

Што се тиче речника књижевног језика, ситуација се компликује због различитих раслојавања таквог језика, због разлике између норме и узуса (укључујући и идосинкратичке појаве у језичкој пракси) и због дијахроног аспекта књижевног језика, који не обухвата само синхрони слој него и сачуване текстове. Овоме треба додати и евентуалну неуједначеност правописних решења у вези са тзв. састављеним и растављеним писањем речи.

Посебан проблем за одређивање фонда лексема представља статус конкретних ономастичких јединица.

А не треба заборавити да све речи (као и мање и веће језичке јединице) могу да буду употребљене аутонимно ${ }^{8}$, тј. да представљају саме себе (тзв. suppositio materialis), а не да означавају нешто друго (тзв. suppositio formalis); нпр.: (2)

„Вода” (или Вода) је именица женског рода. ${ }^{9}$

3. Граматички системи у принципу чине затворене и углавном стабилне класификационе и парадигматске системе и скупове образаца, али

7 Не треба заборавити да нове речи могу да постану извор нове породице речи, а у неким случајевима, захваљујући више-мање регуларној творби, одмах потенцијално постоје и одговарајуће изведенице (нпр. глаголска именица од новог глагола, присвојни придев од одређених типова нових именица, прилог за начин од описног придева и сл.). Нове речи могу да подразумевају и потенцијална значења захваљујући више или мање продуктивним семантичким процесима (нпр. градивна именица може да означи врсту и сл. дате материје, име сликара може да се метонимијски употреби као ознака његове слике итд.). Уз то, нове променљиве речи проширују лексикон и својим граматичким облицима.

8 Таква употреба је у штампаном тексту обично обележена курзивом или наводницима.

9 УП. и:

„A” је вокал, - „A” је прво слово азбуке. - „a” је наставак за номинатив једнине. - „Топла вода” је именичка синтагма. - „Ако дођем” је условна реченица. 
су и они у извесној мери „расплинути”. Томе доприноси и динамичност језика уопште, и дијахрона димензија и раслојеност књижевног језика, разни степени граматикализованости појединих помоћних речи и израза и др.

4. И у вези са лексиконом и у вези са граматичким системима ситуација постаје несравњиво „расплинутија” кад се са језика пређе на његов лингвистички приказ, тј. кад се размотре постојећи речници и граматике. Наиме, ту због непотпуног, непрецизног или нетачног приказа и због неслагања лингвиста постају „расплинути” и делови језика који то у стварности нису. ${ }^{10}$

\section{3. Повезаност језика и реченица}

Треба разликовати два аспекта међуодноса језика и текстова: продукцију и интерпретацију. Што се продукције тиче, синтаксички систем и лексикон регулишу систем (am)ску продукцију (= реализацију) реченица у комуникацији, и у том смислу постоји интерфејс између реализованих реченица и синтаксичког система и лексикона. Шире узев, то је и интерфејс између текстова реализованих у (усменој или писаној) комуникацији и наведених компоненти језика, јер су реченице не само комуникативно-синтаксичке јединице него и сегменти (и фрагменти) текста.

Што се пак интерпретације реченица тиче, ради се о томе да саговорник (односно читалац) треба да успостави синтаксичку структуру и лексичко-морфолошки састав реализованих реченица, и то на основу њихове реализоване материјалне форме. Проблем који се ту јавља, и то на разним нивоима, јесте хомонимија и са њом повезана појава паразитских лексичких и граматичких значења.

Као један пример оваквих појава навешћемо следећи случај, који би се могао назвати интралексемском хомонимијом. Наиме, кад је у реченици употребљена нека полисемична лексема, при интерпретацији се јавља проблем разумевања значења ради кога је говорник употребио ту лексему, тј. изабраног значења (у следећим примерима то значење обележено је скраћеницом и). То подразумева и елиминацију осталих, тј.

${ }^{10}$ Као примери би могла да послуже питања: колико тачно има глаголских облика у српском (или у хрватском) књижевном језику, и који су?, да ли заиста има седам падежних облика?, колико има вредности категорије граматичког броја?, колико има предлога (и предлошких израза) и везника (и везничких израза), и који су? 
конкурентних, значења, која представљају невољно и несвесно енкодирана, дакле паразитска, значења (обележена са п), заснована на семантичкој поливалентности дате речи.

Конкретни пример интралексемске хомонимије представља лексема „жетелица”, која може бити употребљена - послужићемо се дефиницијама из Речника Матице српске - као:

1. женска особа која жање.

2. машина, строј који жање.

Стога је следећа реченица:

(3) Марко је гледао (ту) жетелииу $y^{1 / 2}$.

у принципу двозначна (што је обележено навођењем бројки које идентификују конкурентна значења). Но са гледишта стварне комуникације ту се крију две ситуације, према томе које је од два значења изабрано, а које паразитско:

(4) Марко је гледао (ту) жетелии $y^{1=n / 2=п}$.

(5) Марко је гледао (ту) жетелии $y^{2=и / 1=\pi}$.

Одмах треба додати да разни фактори (који нису потпуно исти у усменој и писаној комуникацији) могу да неутралищу потенцијалну двозначност; ево два примера у којима семантичке рестрикције на појам употребљен у функцији објекта блокирају једно од конкурентних значења.

(6) Марко је задиркивао (ту) жетелииу $1^{1 / 2}$.

(7) Марко је поправио (ту) жетелииу ${ }^{* 1 / 2}$.

Ако се случајевима интралексемске хомонимије додају и случајеви интерлексемске, морфолошке и синтаксичке хомонимије ${ }^{11}$, онда се види да интерфејси реченица (и шире, текстова) и синтаксичког система односно лексикона представљају, кад је о интерпретацији реч, посебну појаву и да се поред изабраног може јавити и паразитски интерфејс.

${ }^{11}$ О интралексемској и морфолошкој хомонимији в. Поповић 1996: 96-98, а о синтаксичкој хомонимији и могућностима неутрализације њоме створене двозначности (енгл. disambiguation) в. Поповић 1978. и 1985, а и Поповић 1979 и 1980. 


\section{4. Интерфејси синтаксичког система, лексикона и реченица} и текстова

Наведени интерфејси (сумеђе) синтаксичког и других граматичких система, лексикона и текстова могу се приказати следећим дијаграмом, с тим што треба рећи да су - ради повезивања са лингвистичким описом компонентама језика и текстовима помоћу знака $\Leftarrow$ придружени и одговарајући лингвистички прикази, тј. граматике, речници (= дикционари) и корпуси:
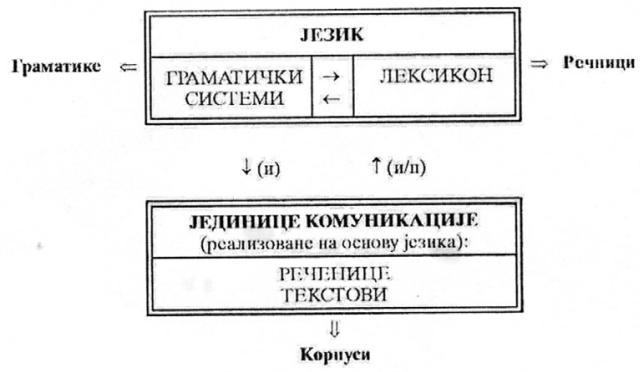

2. Речи као јединице преко којих се повезују синтаксички систем, лексикон и реченице ${ }^{12}$

2.1. Продукција реченица: потенцијалне и реализоване текстуалне речи

Посматрана као материјализовани језички израз којим треба да се реализује једнозначна порука, (комуникативна) реченица у свом сегменталном аспекту (одн. компоненти) представља уређену и завршену секвенцу (= ниску) речи као јединица од којих свака има следеће карактеристике: (1) фонетско-фонолошки или графичко-графемски израз (укључујући и електронски запис) којим се материјализује (2) пунозначна или помоћна лексема, и то (2.a) употребљена (ако је полисемична) у једном свом значењу; (3) граматички класификована (у том свом значењу) у оквиру система врста речи и класификационих категорија, и то (3.а) са по једном конкретном вредношћу сваке полисемичне (одн. поливалентне) граматичке класе; (4) употребљена (ако је променљива) у одређеном граматичком облику, и то (4.a) са по једном конкретном вредношћу сваке полисемичне (одн. поливалентне) морфолошке категорије

12 Више о појединим питањима из овог одељка в. у: Поповић 1996. 
реализоване граматичким обликом (нпр. ако се ради о презенту, онда је то или референтни апсолутни презент, или апсолутни или релативни квалификативни презент, или футурски презент, или приповедачки презент итд.). Овоме ће, у тачки 2.2. бити додато као (5) и следеће: лексеме (у значењу у коме су употребљене), ако то захтевају синтаксичка правила, треба да припадају одређеној лексичко-синтаксичкој (пот)класи. (Реченица, наравно, подразумева и постојање прозодијског односно правописно-графичког аспекта, тј. интонације, реченичног акцента, пауза итд. односно белина, знакова интерпункције, почетног великог слова итд.).

Овако схваћене речи могу се означити као (реализоване) текстуалне речи. А одговарајуће јединице лексикона, чији избор претходи материјализацији реченице, могу се означити као потенцијалне текстуалне речи. У том случају - остављајући по страни проблем фразеологизама и других израза - јединице преко којих при језичкој продукцији долази до изражаја интерфејс лексикона и реченица (и текстова) јесу реализоване и потенцијалне текстуалне речи. А речник о коме се ради, и који у суштини представља један од подскупова садржаних у лексикону датог језика, јесте речник потенцијалних текстуалних речи.

Овде треба додати и једну напомену: све реализоване текстуалне речи не морају да потичу из лексикона, чак и ако се лексикон схвати као расплинути скуп. Један пример је текстуална реч иконабуле из реченице:

(8) Предсједницима југословенских република биће уручено фототипско издање „Охтоиха”, прве иконабуле на Балкану... (Борба, 29. IV 1991, стр. 1).

Јер лексема „иконабула” није члан лексикона (а ни постојећих дикционара) српског (ни хрватског) књижевног језика, где постоји само „инкунабула” (или „инкунабул”). ${ }^{13}$ То је, дакле, идиосинкратична реч из ауторовог идиолекта (или штампарска грешка).

13 Оваквим идиосинкратизмима (којих има разних врста) могле би се додати разне грешке односно омашке у говору, а посебно у писању (куцању, штампању). На пример, данас, у ери рачунара, све су чешће грешке настале услед небрижљиве конверзије алфабета, као и у реченици:

... Одељењу унутрашњих послова Земун предао револвер (марке Смитх Вессон [уп. енгл. Smith, Wesson], калибар 38 мм (Наша Борба, 10-11. II 1996, стр. 6). (О оваквим појавама в. Витас 1993: 2.26 sq.) 


\section{2. Продукција реченице: системске текстуалне речи}

Синтаксички систем регулише употребу потенцијалних и преко њих и реализованих текстуалних речи, и то оним својим правилима (обрасцима, подсистемима и сл.) која у себи садрже системске текстуалне речи (или њихове пројекције на шире јединице, пре свега синтагме у којима су те речи центри). А под тим термином треба подразумевати два типа варијабли (променљивих) које као конкретне вредности добијају одговарајуће потенцијалне, а преко њих и реализоване, текстуалне речи. Један тип су пунозначне системске текстуалне речи, тј. текстуалне речи схваћене као слободне варијабле којима одговарају одређене класе потенцијалних текстуалних речи у лексикону и реализације тих речи у реченици. Таква је варијабла, нпр. именица у номинативу (једнине и множи$\boldsymbol{н е ) , ~ к а о ~ ј е д и н и ц а ~ к о ј а , ~ н п р . , ~ у ч е с т в у ј е ~ у ~ с п е ц и ф и к а ц и ј и ~ с а с т а в а ~ с у б ј е к т а . ~}$ Тој варијабли одговарају текстуалне речи књига, књиге, родитељ, родительи, факултет, факултети итд. итд. (наравно, увек као моносемичне одн. моновалентне јединице у свим елементима у којима постоји могућност полисемије одн. поливалентности). Други тип су помоћне системске текстуалне речи, тј. текстуалне речи схваћене као везане варијабле, одн. као варијабле којима је придружен одређени члан дате класе; нпр. појам предлог о, који се, између осталог, јавља у спецификовању рекције неких типова глагола, јесте варијабла (уп.: предлог), али индивидуализована (уп.: o).

Према томе, јединица синтаксичког система преко које се успоставља интерфејс тога система и лексикона односно реченице јесте системска текстуална реч.

Што се лексикона тиче, то је и у овом случају фонд граматички систематисаних лексема и њихових облика, али у форми речника потенцијалних текстуалних речи. Штавише, за продукциону примену синтаксичког система битна је морфосинтаксичка компонента (аспекат) текстуалних речи, тј. њихова систематисаност (класификованост) с обзиром на врсте речи и граматичке категорије. Ако се ова компонента реификује као морфосинтаксичка реч ${ }^{14}$, онда се може рећи да је за продукциони интерфејс синтаксичког система и лексикона битан речник морфосинтаксичких речи, наравно повезаних са корелативним језичким материјалним обликом текстуалних речи, тј. њиховом формалном компонентом (аспектом), која се може реификовати као формална реч.

14 Пошто се ради о речи, подразумева се да морфосинтаксичка реч поред граматичких карактеристика има и (једно одређено) лексичко значење. 


\section{3. Сужавање примене слободних системских варијабли} на лексикон

Системска реч је категоријална реч, и то у том смислу је дефинисана општим граматичким класификацијама (врста и подврста речи и одговарајуће вредности класификационих и морфолошких категорија). Другим речима, системска реч се у принципу односи на све чланове дате класе, с тим што изузетак од тога представљају везане системске речи јер су везивањем ограничене на одређени члан (или чланове) дате класе. Међутим, оно што веома често карактерише примену слободних варијабли (а то су углавном пунозначне речи) јесте суженост (ограниченост) те примене. Показаћемо то на следећем примеру.

Ако би се рекло да именица у инструменталу множине има значење временске мере (колико дуго?), онда би се такво значење очекивало и код потенцијалних текстуалних речи као што су: оловкама, возовима, пољима итд., јер су и то именице у инструменталу множине. То, наравно, није случај, него се ради о речима као што су: сатима, данима, месецима итд. Неопходно је, дакле, сузити одн. ограничити примену системске речи. У овом случају, и у већини других оваквих случајева, стварна вредност системске речи је одређена семантичка класа текстуалних речи (у овом случају се ради о јединицама мере времена). Дакле, уопштено говорећи, системске речи као своје вредности врло често добијају само једну или више одређених лексичких класа, и то пре свега семантичких лексичких класа.

Тиме се, међутим, не исцрпљује ова проблематика. Наиме, могу постојати изузеци од лексичке класе на коју је сужена примена системске речи, тј. могу постојати чланови те класе који не представљају вредност системске речи. У овом случају такви изузеци су секундама, минутима, јер се те текстуалне речи не употребљавају са одредбеним значењем мере времена; нпр. следећа реченица:

(9) Чекао ју је секундама (и минутима).

била би сасвим необична.

Остављајући да о овим питањима (укључујући и наведени пример) подробније говоримо на другом месту, овде бисмо истакли огромну важност ових појава за лингвистичку методологију и конкретна истраживања. Наиме, ако се жели задовољити принцип „све и само”, тј. да се спецификују све вредности које добија дата варијабла и само оне, а не и неке друге, онда је неопходно тачно одредити да ли се ради о категоријалној варијабли или постоји супкатегоријална лексичка класифи- 
кација. А у овом другом случају треба одредити о каквој се класи или класама ради и да ли ту има изузетака. Једном речи, треба формулисати интегрално правило, које ће поред чисто граматичке (категоријалне) обухватити и релевантну лексичку (супкатегоријалну) информацију. С друге стране, да би таква информација заиста дала ефекат, потребно је у речнику којим се приказује лексикон датог језика на одговарајући начин супкласификовати све текстуалне речи којих се дато правило тиче. Значи да и приказ речника треба да буде интегралан, у овом случају да садржи и синтаксички релевантну лексичку информацију. ${ }^{15}$

\section{4. Неке дискрепанције између системских и потенцијалних и реализованих текстуалних речи}

У неколико случајева долази до појаве нешто другачијих интерфејса који повезују синтаксички системи, лексикон и реченице. Један случај, у оквиру кога постоје два типа (који се могу комбиновати), јесте да се у синтаксичком правилу јавља једна системска реч, а да њена примена подразумева појаву две или више потенцијалних односно реализованих текстуалних речи. Такав је случај када се као носилац предиката јавља глагол у личном облику, јер (1) постоје повратни глаголи, који су двочлани (глаголска лексема и речца $c e)^{16}$ и (2) сложени глаголски облици (активни и пасивни), код којих се уз главни глагол јављају један или два помоћна глагола. Ако се као глаголски облици узму и одрични (евентуално и упитни) облици, онда су могуће и комбинације као што је не би се био бојао и сл. У вишечлане лексеме спадају и заменице типа ко год, било

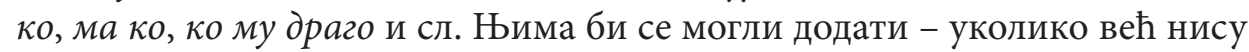
део синтаксичког правила - и помоћни изрази, као што су: да ли (бар у писаном тексту), пре него што, а камоли, с обзиром на итд., мада ту остаје питање да ли се заиста ради о изразу (уп. да ли) односно да ли је то израз или комбинација помоћних речи (пре него што, а камоли, с обзиром на и др.). У сваком случају, што се писаног језика тиче, колико ће бити вишечланих лексема и њима сродних израза зависи од правописа (а разни правописи се ту не подударају), као и од правописне исправности напи-

15 За однос синтаксичког система и лексикона важне су и творбене везе међу лексемама јер ту долази до „наслеђивања” синтаксички релевантних карактеристика.

16 Оваква комбинација се добија и када се ради о нерефлексивном глаголу употребљеном у рефлексном облику (у пасивној или безличној конструкцији). 
саног текста. А слично важи и за полусложенице, које су такође јединице које садрже више од једне текстуалне речи. ${ }^{17}$

С друге стране, при реализацији две потенцијалне текстуалне речи може доћи до универбизације (такав је, бар у писању, случај футура са постпонованом енклитиком, сем ако се глагол завршава на $\hbar u,{ }^{18}$ и употреба дугог се уместо се је, бар како се та и сродне такве појаве традиционално тумаче). ${ }^{19}$ А универбизацији би се евентуално могле додати и неке елипсе, укључујући и тип: хидро и електроцентрале.

Још једна појава је дисконтинуирана реализација речи, позната и као тмеза, односно раздвајање делова (сложене) речи, нпр. ни од кога и сл. (таквих појава је у старијем језику било и више). ${ }^{20}$

И додавање навезака доводи до раскорака између реализоване и изабране потенцијалне текстуалне речи (о навесцима в. Анић 1975).

\section{5. Интерпретација реченица: значај формалних речи}

Прималац поруке (саговорник, слушалац, читалац) суочен је са материјализованим језичким обликом (фонетским или правописним) реализованих текстуалних речи, тј. са формалним речима оствареним у одговарајућем медију комуникације. Његов задатак је да свакој формалној речи придружи одговарајући садржински део, тј. морфосинтаксичку реч коју је изабрао пошиљалац поруке. При томе је суочен са хомонимношћу највећег броја текстуалних речи, чије се размере могу схватити тек ако се узме у обзир обим полисемије и код лексема (интралексемска хомонимија) и код разних граматичких категорија.

Дакле, јединице контакта реченица и лексикона јесу реализоване и потенцијалне формалне речи. А речник текстуалних речи за примаоца поруке представља речник текстуалних речи сагледаних из њиховог формалног аспекта, тј. речник формалних речи, којима су придружене

17 Уп. и ad hoc спојене речи, као у примеру:

„... свађао се са другим уредницима шта-може-а-шта-не-може да иде у број” (М. Пантић, у: Најлепше српске приче, Београд, 1990, стр. 191).

18 Уп. и некадашње знадбудем и сл., а и немам (према не имам) и сл.

${ }_{19}$ Својеврсну универбизацију представља и образовање акценатских целина изговарањем проклитика и енклитика заједно са акцентованом речи, чиме тзв. фонетска реч постаје шира од текстуалне речи.

${ }^{20}$ Један случај идиосинкратичне тмезе (и то код изведене речи) илуструје следећа реченица:

И онда је тиш усред ине зазвонио телефон (С. Басара, у: Најлепше српске приче, Београд, 1990, стр. 181). 
све морфосинтаксичке речи које се реализују истом формалном речи (истим материјалним језичким обликом).

Формална реч у исто време представља и почетну јединицу преко које су при интерпретацији повезане реченице и синтаксички систем (на основу кога се врши интерпретација синтаксичке структуре) и синтаксички систем и лексикон, јер се та интерпретација врши уз лексичку и морфосинтаксичку идентификацију текстуалних речи исказаних реализованим формалним речима.

И овде треба додати да могу постојати одређене дискрепанције између реализованих и потенцијалних и системских формалних речи, само што те дискрепанције нису увек исте у разним медијима. На пример, у изговору реченица:

(10) Нико га не слуша.

(11) Никога не слуша.

постоји фонетска реч /ň̀koga/, која се може тумачити као једна или као две формалне речи. ${ }^{21}$

Још један пример пружа реченица:

(12) Успут ... у трку нас је достигла дугонога дјечачица ..., у трку нам назвала „доброј'тро”... (Б. Ћопић, Доживљаји Николетине Бурсаћа, Београд, 1963, стр. 13).

где и у изговору, а не само у писању, треба претпоставити својеврсну несистемску универбизацију.

\section{3. Закључци}

Системска природа језика и двострука функционална веза продукциона и интерпретациона језика и текстова подразумевају постојање одговарајућих међуодноса и веза, тј. одговарајућих интерфејса (сумеђа).

Речник (лексикон) са гледишта повезивања са синтаксичким системом и реченицама (текстовима) јавља се као двоструки скуп: (1) као речник потенцијалних текстуалних речи или, још конкретније, као речник морфосинтаксичких речи спојених са одговарајућим формалним речима и (2) као речник потенцијалних формалних речи спојених са свим (хомолексемским и хетеролексемским) морфосинтаксичким речима које се јављају као њихови корелати на плану садржине (с тим што ту,

21 Овај пример проблема сегментације реченице преузет је из Поповић 1978: 96. 
због разлика у обиму формалног подударања текстуалних речи, треба разликовати речник говорног и речник писаног језика).

На плану лингвистичких истраживања, ово подразумева да би опис синтаксичког односно граматичког система и приказ лексикона требало да буду уско координирани и да стоје у корелацији. Другим речима, граматичка правила би морала да буду формулисана тако да поред категоријалне компоненте садрже и конкретизацију неопходну за адекватну примену на јединице речника, тј. да буду интегрална правила; а приказ лексикона би морао да садржи сву синтаксички (и шире, граматички) релевантну информацију, тј. да буде интегрални лексикон.

Уз то би приказ и једне и друге компоненте језика требало да одражава и стварну ситуацију у језичким корпусима.

Дакле, у приказу и језика и његове употребе требало би колико је могуће водити рачуна о одговарајућим интерфејсима у оквиру описа, који се могу приказати следећим дијаграмом:

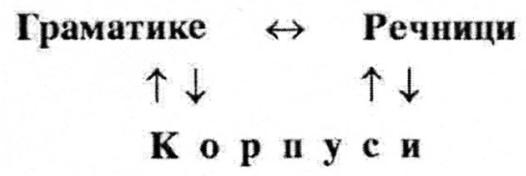

При том је потребно водити рачуна и о оба функционална аспекта језика, тј. поред приказа везаног за продукцију обрађивати лингвистичке чињенице и из интерпретационе перспективе. Једном речи, потребан је интегрални приступ проучавању језика и његове употребе, при коме ће све више долазити до изражаја сва сложеност и интегрисаност компоненти језика и њихове примене у комуникацији.

\section{ЛИТЕРАТУРА}

Анић 1975: Vladimir Anić, „Navezak u suvremenom jeziku”, Jezik, XXIII/1, str. 15-25.

Витас 1993: Duško Vitas, Matematički model morfologije srpskohrvatskog jezika (imenska fleksija) [doktorska disertacija], Beograd.

Поповић 1978: Љубомир Поповић, „О двозначним конструкцијама”, Наш језик, XXIII/3-4, стр. 95-103.

Поповић 1979: Љубомир Поповић, „О неким појавама амбигвитета у вези са комбиновањем детерминације и координације", Наш језик, XXIV/12, стр. 3-20. 
Поповић 1980: Ljubomir Popović, „O dvoznačnim konfiguracijama sa potencijalno impliciranim determinantima”, Јужнословенски филолог, XXXVI, стр. 25-46.

Поповић 1985: Ljubomir Popović, „Gramatički sistem i sintaksička homonimija”, Zbornik sa III. znanstvenega srečanja Računalniška obdelava jezikovnih podatkov, Bled, стр. 225-238.

Поповић 1996: Љубомир Поповић, „Морфосинтаксичке ниске”, Сриски језик, I/1-2, стр. 90-101.

Ljubomir Popović

AN INTEGRAL MODEL OF THE INTERRELATIONSHIPS OF THE SYNTACTIC SYSTEM, THE LEXICON AND TEXTS

Summary

This paper attempts to specify and explain the interfaces which exist between the syntactic system, the lexicon and texts in sentence production and interpretation, and stresses the need for an integral approach to the formulation of grammatical rules and presentation of the lexicon. 